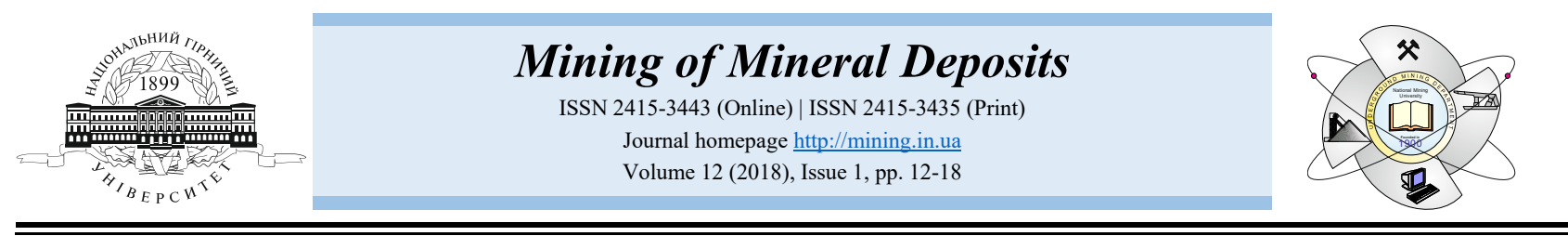

UDC 622.765 .061

https://doi.org/10.15407/mining12.01.012

\title{
OPTIMIZATION OF MOLYBDENITE FLOTATION USING RESPONSE SURFACE METHOD
}

\author{
R. Badri ${ }^{1 *}$, A.R. Khanchi ${ }^{2}$, A.R. Zojaji ${ }^{1}$, A.A. Rahmani ${ }^{3}$ \\ ${ }^{1}$ University of Tehran, Tehran, Iran \\ ${ }^{2}$ Nuclear Science and Technology Research Institute, Tehran, Iran \\ ${ }^{3}$ University of Imam Khomeini, Qazvin, Iran \\ ${ }^{*}$ Corresponding author: e-mail rezgarbadri08@yahoo.com, tel.+982126762260,fax: +982166480290
}

\begin{abstract}
Purpose. The paper is aimed to study the molybdenite flotation from a low-grade uranium ore containing $0.2 \%$ of Mo.

Methods. Three control parameters including frother (MIBC) dosage, collector (gasoline) dosage and $\mathrm{pH}$, each in five levels, were investigated. Response surface methodology (RSM) was performed for statistical design and analysis of experiments and process modeling. Four quadratic mathematical models were derived for prediction of Mo recovery and Mo grade.

Findings. Analysis of variance showed that frother and collector dosage were the most significant factors affecting Mo recovery and grade. In process optimization, maximum values of Mo recovery and grade were achieved as $79.13 \%$ and $2.93 \%$, respectively. Optimum frother concentration of $78.93 \mathrm{~g} / \mathrm{t}$, gasoline dosage of $507.70 \mathrm{~g} / \mathrm{t}$, and $\mathrm{pH}$ of 9.77 , for Mo recovery were obtained. However, in optimization studies, a case proposed the model in which the same consumption of reagents is used.
\end{abstract}

Originality. There is a recognized need for type of uranium ore which contains Molybdenite, therefore working on molybdenite removing from this ore helps to recover uranium in the next steps. This research provides a novel approach to gain the optimum recovery and grade to extract uranium so easily.

Practical implications. This study showed that response surface methodology could be effectively used for flotation process modeling as well as finding an optimum condition to achieve maximum recovery and grade under minimum consumption of flotation reagents.

Keywords: molybdenite, flotation, response surface methodology, central composite design, design of experiments

\section{INTRODUCTION}

Response surface methodology (RSM) is a collection of statistical and mathematical techniques useful for the modelling and analysis of problems in which a response of interest is influenced by several variables and the objective is to optimize this response (Grice \& Montgomery, 2000).

In most RSM problems, the relationship between dependent and independent variables is unknown. Thus, the first step in RSM is to find a suitable approximation for a functional relationship between dependent and independent variables. If there is a curvature in the system, then a polynomial of higher degree is used. Second-order models are widely used in response surface methodology as they have several advantages. They are very flexible and can take on a wide variety of functional forms so they will work well as an approximation to the true response surface. Moreover, it is easy to estimate the parameters in a second-order model using the method of least squares (Grice \& Montgomery, 2000).

Central composite design (CCD) contains five levels of each factor: low axial, low factorial, center, high factorial, and high axial. With this many levels, it generates nough information to fit a second-order polynomial (Mason, Gunst, \& Hess, 2003; Anderson \& Whitcomb, 2007).

Sedimentary uranium rocks may contain molybdenite that its grade changes from a few ppm to more than $0.5 \%$. The small amount of molybdenum interferes with the recovery of uranium so it must be separated (Gupta, 1992).

The major technologies involving molybdenum compounds viz catalysis, lubrication, refractories, paints and allied industries and agriculture are well established. Because of the molybdenite structure and bonds, its natural floatability, compared with other minerals is high (Garner, 1994). 
As Fuerstenau, Jameson, \& Yoon (2007) stated that the best method to separate molybdenite from other minerals is flotation and mentioned the industrial instances of molybdenite flotation. Shirley and Sutulov (1985) and Hernlund (1961) explained some effective factors on floatability of molybdenite such as: ore deposit mineralogy, slime coatings, grinding and liberation and flotation reagents. Zanin, Ametov, Grano, Zhou, \& Skinner (2009) described the variation of molybdenite from operation to operation and conducted experiments within different ore bodies.

Some researchers by focusing on the chemical changes in reagents, suggested some methods to conduct the experiments for enhancing the best recovery. Triffett, Veloo, Adair, \& Bradshaw (2008) proposed several changes to increase molybdenum recovery and then optimized frother to collector ration to earn adequate froth stability.

Biswas and Davenport (2013) explained that Kerosene and fuel oil are good collectors for molybdenite and used potassium amyl xanthate as scavenger flotation. In other researches (Schena \& Casali, 1994; Bulatovic, Wyslouzil, \& Kant, 1998; Rath \& Subramanian, 1999; Rubio, Capponi, Rodrigues, \& Matiolo, 2007) kerosene, vapor oil, fuel oil, transformer oil and other hydrocarbons were used in direct flotation of molybdenite. Additionally, Yin, Zhang, \& Xie (2010) used kerosene as the collector in Xinhua Molybdenum Flotation Plant (Liao- ning, China). Thus the floatability of molybdenite is enhanced if an insoluble, nonpolar hydrocarbon oil is added to flotation cell (Smit \& Bhasin, 1985). Therefore, fuel oil used as collector in this study and methyl isobutyl Carbinol (MIBC) used as frother.

The main objective of this research was first to establish a functional relationship between three process variables (frother dosage, collector dosage, and pulp $\mathrm{pH}$ ) and the flotation characteristics (Mo recovery, Mo grade of molybdenite concentrate), using a statistical technique. Central composite design approach was used to determine significant factors that affect the molybdenite flotation and to develop quadratic mathematical models for the optimization of the process. Consequently, the responses were maximized using the minimum consumption of molybdenite flotation reagents.

\section{MATERIALS AND METHODS}

\subsection{Molybdenum ore characteristics}

The low-grade ore sample containing $0.2 \%$ Mo was obtained from Narigan Uranium ore, Iran. For ore characterization, optical mineralogy, using the polished and thin sections, as well as x-ray diffraction techniques (XRD) were used. The XRD analysis of the original ore sample is also given in Table 1.

Table 1. XRD analysis of molybdenite sample

\begin{tabular}{lcccccccccc}
\hline \multicolumn{1}{c}{ Compose } & $\mathrm{Na}_{2} \mathrm{O}$ & $\mathrm{MgO}$ & $\mathrm{Al}_{2} \mathrm{O}_{3}$ & $\mathrm{SiO}_{2}$ & $\mathrm{P}_{2} \mathrm{O}_{5}$ & $\mathrm{SO}_{3}$ & $\mathrm{Cl}$ & $\mathrm{K}_{2} \mathrm{O}$ & $\mathrm{CaO}^{2}$ & $\mathrm{TiO}_{2}$ \\
\hline Concentration (\%) & 0.55 & 2.05 & 11.95 & 61.75 & 0.47 & 5.28 & 0.0003 & 2.83 & 6.86 & 0.82 \\
intensity & 1.9 & 33.7 & 604.8 & 5569.3 & 58.6 & 1114.6 & 8.9 & 987.6 & 3004.2 & 582.8 \\
compose & $\mathrm{Cr}_{2} \mathrm{O}_{3}$ & $\mathrm{MnO}$ & $\mathrm{Fe}_{2} \mathrm{O}_{3}$ & $\mathrm{CuO}$ & $\mathrm{Zn}$ & $\mathrm{As}_{2} \mathrm{O}_{3}$ & $\mathrm{ZrO}_{2}$ & $\mathrm{UO}_{2}$ & $\mathrm{MoO}_{2}$ & \\
Concentration (\%) & 0.055 & 0.19 & 6.24 & 0.05 & 0.21 & 0.14 & 0.04 & 0.06 & 0.20 & \\
intensity & 89.6 & 527.8 & 17355.3 & 56.2 & 401.4 & 462.6 & 351.4 & 255.1 & 659.8 & \\
\hline
\end{tabular}

\subsection{Experimental and modelling procedures}

\subsubsection{Flotation experiments}

Flotation experiments were carried out in 2.51 Denver laboratory flotation cell using $252 \mathrm{~g}$ ore sample. Gasoline and methyl isobutyl carbonyl (MIBC) were used as flotation collector and frother, respectively. The control factors and their levels were selected in the light of the feasibility flotation experiments and literature review.

Based on the previous studies three factors showed more influence on the process. The selected control factors, including frother dosage, collector dosage and pulp $\mathrm{pH}$ and their levels are shown in Table 2.

Table 2. The level of variables in the Central composite design

\begin{tabular}{lccccc}
\hline \multicolumn{1}{c}{ Variable } & $\begin{array}{c}\text { Low } \\
\text { axial } \\
(-1.68)\end{array}$ & $\begin{array}{c}\text { Low } \\
\text { factorial } \\
(-1)\end{array}$ & $\begin{array}{c}\text { Center } \\
(0)\end{array}$ & $\begin{array}{c}\text { High } \\
\text { factorial } \\
(+1)\end{array}$ & $\begin{array}{c}\text { High } \\
\text { axial } \\
(+1.68)\end{array}$ \\
\hline $\begin{array}{l}\text { A: Frother } \\
\text { dosage }\end{array}$ & 63 & 70 & 80 & 90 & 97 \\
$\begin{array}{l}\text { (MIBC) }(\mathrm{g} / \mathrm{t}) \\
\begin{array}{l}\text { B: Collector } \\
\text { dosage }\end{array}\end{array}$ & 432 & 500 & 600 & 700 & 768 \\
$\begin{array}{l}\text { Gasoline })(\mathrm{g} / \mathrm{t}) \\
\mathrm{C}: \mathrm{pH}\end{array}$ & 7.8 & 8.5 & 9.5 & 10.5 & 11.1 \\
\hline
\end{tabular}

Each factor varied in five levels, whereas the other operational parameters of flotation were kept constant. Pulp density of $20 \%$ solid, conditioning time of $10 \mathrm{~min}$ for collector, and conditioning time of $1 \mathrm{~min}$ for frother, the froth collection time of $7 \mathrm{~min}$ and rotor speed of $1200 \mathrm{rpm}$ were used in all of the flotation experiments.

\subsubsection{Central composite design}

The most frequently used second-order designs are the $3^{\mathrm{k}}$ factorial, central composite, and the Box-Behnken designs. Central composite design (CCD) is the most popular response surface method (Grice \& Montgomery, 2000; Mason, Gunst, \& Hess, 2003; Anderson \& Whitcomb, 2007). This design consists of the following three portions:

- a complete (or fractional) factorial design, whose factors' levels are coded as $-1,1$;

- an axial design, often a star design in which experimental points are at a distance of $\alpha$, from its center;

- a central point.

The quadratic model, which is a second order polynomial, could be fitted using these levels. Fitting of the model can be computed by a standard statistical software. Using the statistical software packages, like "design of experiments" (DX7), based on RSM, the optimum flotation factors could be achieved with the minimum number of experiments. To define a central point, the polynomial function should be contained quadratic terms according to the following equation:

$$
Y=\beta_{0}+\sum_{i=1}^{k} \beta_{i} x_{i} \sum_{<i<j}^{k} \beta_{i i} x_{i}^{2}+\sum_{1<i<j}^{k} \beta_{i j} x_{i} x_{j}+\varepsilon,
$$


where:

$k, \beta_{0}, \beta_{i}, x_{i}, \beta_{i i}, \beta_{i j}$ and $\varepsilon-$ number of variables, constant term, coefficients of the linear parameters, variables, coefficients of the quadratic parameters, coefficients of the interaction parameters and residual associated with the experiments, respectively (Bezerra, Santelli, Oliveira, Villar, \& Escaleira, 2008).

\section{RESULTS AND DISCUSSION}

\subsection{Construction of model equations}

Twenty flotation experiments were designed using central composite design methodology. The experimental conditions and their responses are shown in Table 3.

\begin{tabular}{|c|c|c|c|c|c|c|c|c|}
\hline & \multicolumn{2}{|c|}{$\begin{array}{c}\text { A: Frother } \\
\text { dosage }\end{array}$} & \multicolumn{2}{|c|}{$\begin{array}{l}\text { B: Collector } \\
\text { dosage }\end{array}$} & \multicolumn{2}{|c|}{$\mathrm{C}: \mathrm{pH}$} & \multirow{2}{*}{$\begin{array}{l}\text { Reco- } \\
\text { very } \\
(\%)\end{array}$} & \multirow{2}{*}{$\begin{array}{c}\text { Grade } \\
(\%)\end{array}$} \\
\hline Run & Coded & Actual & Coded & Actual & Coded & Actual & & \\
\hline 1 & -1 & 70 & 1 & 700 & 1 & 10.50 & 68.35 & 2.76 \\
\hline 2 & 0 & 80 & 0 & 600 & 1.68 & 11.18 & 64.07 & 2.79 \\
\hline 3 & 0 & 80 & 0 & 600 & 0 & 9.50 & 78.07 & 3.13 \\
\hline 4 & 0 & 80 & 0 & 600 & -1.68 & 7.82 & 64.45 & 2.81 \\
\hline 5 & 0 & 80 & 0 & 600 & 0 & 9.50 & 73.7 & 2.97 \\
\hline 6 & -1.68 & 63.18 & 0 & 600 & 0 & 9.50 & 69.97 & 1.34 \\
\hline 7 & 0 & 80 & -1.68 & 431.82 & 0 & 9.50 & 59.74 & 2.85 \\
\hline 8 & 0 & 80 & 1.68 & 768.18 & 0 & 9.50 & 78.62 & 2.41 \\
\hline 9 & 1 & 90 & -1 & 500 & -1 & 8.50 & 57.25 & 3.2 \\
\hline 10 & 0 & 80 & 0 & 600 & 0 & 9.50 & 77.8 & 2.7 \\
\hline 11 & 0 & 80 & 0 & 600 & 0 & 9.50 & 74.76 & 3.05 \\
\hline 12 & -1 & 70 & 1 & 700 & -1 & 8.50 & 61.98 & 2.1 \\
\hline 13 & 1 & 90 & -1 & 500 & 1 & 10.50 & 65.52 & 2.89 \\
\hline 14 & -1 & 70 & -1 & 500 & -1 & 8.50 & 65.1 & 1.51 \\
\hline 15 & 0 & 80 & 0 & 600 & 0 & 9.50 & 79.11 & 3.07 \\
\hline 16 & 1 & 90 & 1 & 700 & 1 & 10.50 & 74.89 & 1.75 \\
\hline 17 & -1 & 70 & -1 & 500 & 1 & 10.50 & 65.66 & 1.97 \\
\hline 18 & 0 & 80 & 0 & 600 & 0 & 9.50 & 75.15 & 3.1 \\
\hline 19 & 1 & 90 & 1 & 700 & -1 & 8.50 & 69.12 & 1.72 \\
\hline 20 & 1.68 & 96.82 & 0 & 600 & 0 & 9.50 & 74.76 & 1.89 \\
\hline
\end{tabular}

The quadratic models among several models were chosen and fitted to the results in "Design Expert (DX 7)" software. Two models were fitted to Mo recovery and Mo grade.

Quadratic models found to be adequate for the prediction of the response variables are given by the following equations (Mo recovery and Mo grade):

Mo $R=+76.42+0.64 A+3.77 B+1.53 C+$

$+2.08 A B+1.53 A C-0.21 B C-1.49 A^{2}-$

$-3.35 B^{2}-4.95 C^{2}$;

Mo $G=+3.01+0.16 A-0.14 B+0.059 C+$

$+0.50 A B-0.17 A C+0.068 B C-0.50 A^{2}-$

$-0.14 B^{2}-0.078 C^{2}$.

In these models, all variables are in coded values and $A$ is frother dosage, $B$ is collector dosage, $C$ is $\mathrm{pH}$ and $A B, A C$ and $B C$ are interaction of main parameters. The results of analysis of variance (ANOVA) of the developed models are shown in Table 4.
Table 4. The results of ANOVA analysis of the develpoed models

\begin{tabular}{ccccccc}
\hline & & $\begin{array}{c}\text { Sum of } \\
\text { square }\end{array}$ & DOF & $\begin{array}{c}\text { Mean } \\
\text { square }\end{array}$ & $\begin{array}{c}\text { F- } \\
\text { value }\end{array}$ & $\begin{array}{c}\text { P- } \\
\text { value }\end{array}$ \\
\hline Mo & Model & 753.60 & 9 & 83.73 & \multirow{2}{*}{8.09} & 0.0015 \\
recovery & Residual & 103.44 & 10 & 10.34 & & \\
\hline $\begin{array}{c}\text { Mo } \\
\text { grade }\end{array}$ & Model & 6.79 & 9 & 0.75 & \multirow{2}{*}{40.37} & $<0.0001$ \\
\hline
\end{tabular}

It illustrates that all fitted models are significant in 95\% confidence level ( $p$-value $<0.05$ ). Figure 1 and 2 represent predicted against actual values for Mo recovery and Mo grade, respectively.

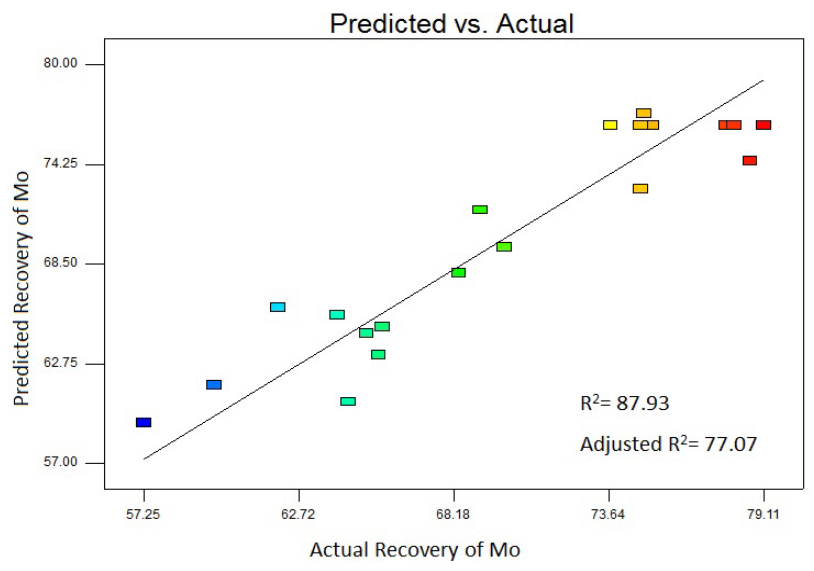

Figure 1. Predicted vs. actual values of Mo recovery, \%

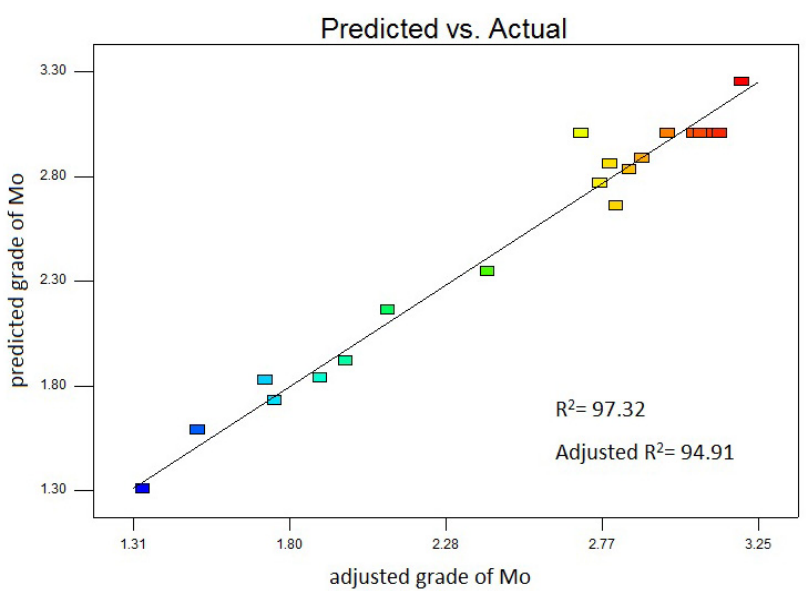

Figure 2. Predicted vs. actual values of Mo grade, \%

Values of R-square for the models are shown in these figures. The high value of $\mathrm{R}$-square indicates that the quadratic equation is capable of representing the system under the given experimental domain. Therefore, according to model interactions between variables have significant effects on responses, so results were presented and discussed in terms of interactions. Figure 3 shows the effect of frother (MIBC) dosage and collector (Gasoline) dosage on the Mo recovery.

It is indicated that Mo recovery depends more on the collector dosage rather than the frother dosage. Accordingly, collector dosage has shown a positive effect on Mo recovery. 


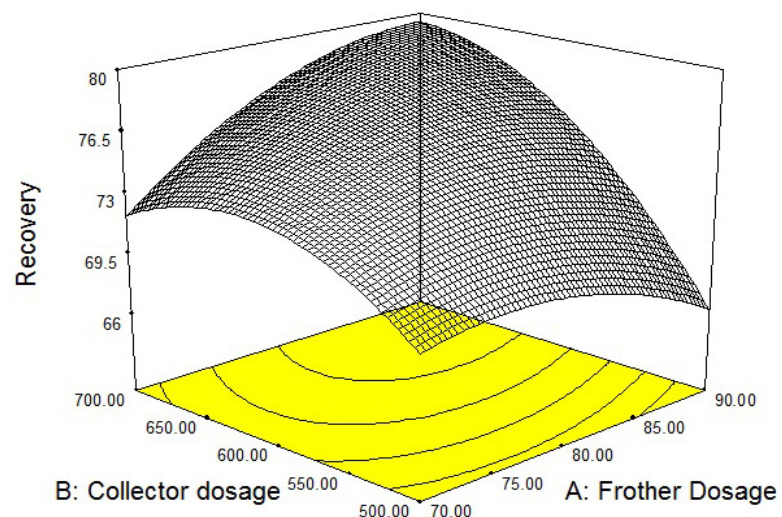

Figure 3. Effect of frother and collector dosages on Mo recovery in $\mathrm{pH} 9.77$

Meanwhile, it has been the most significant factor affecting the Mo recovery in comparison with the other two factors. It can be deduced from Figure 4 that the effects of $\mathrm{pH}$ and collector dosage on the Mo recovery have been positive until the pulp $\mathrm{pH}$ reaches to 9.77 .

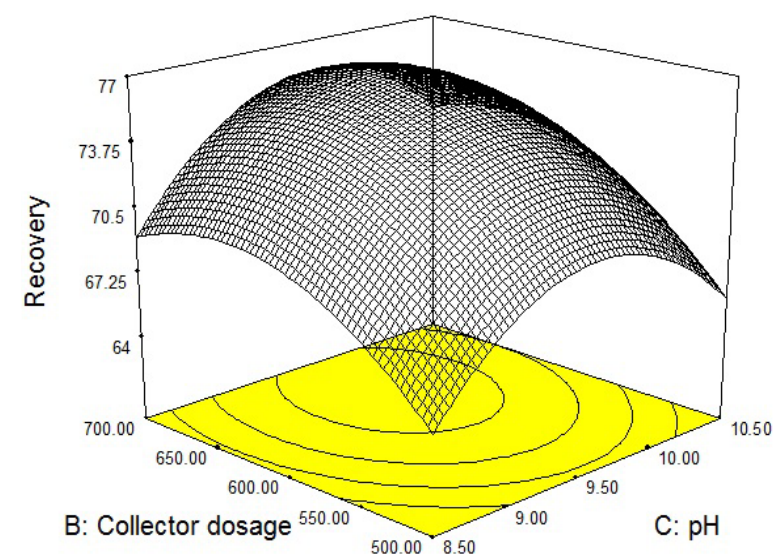

Figure 4. Effect of collector dosage and pH on Mo grade (\%) in frother dosage of $78.93 \mathrm{~g} / \mathrm{t}$

Unlike Mo recovery, Mo grade increased with increasing frother and collector dosage until the specific point and then decreased (Fig. 5).

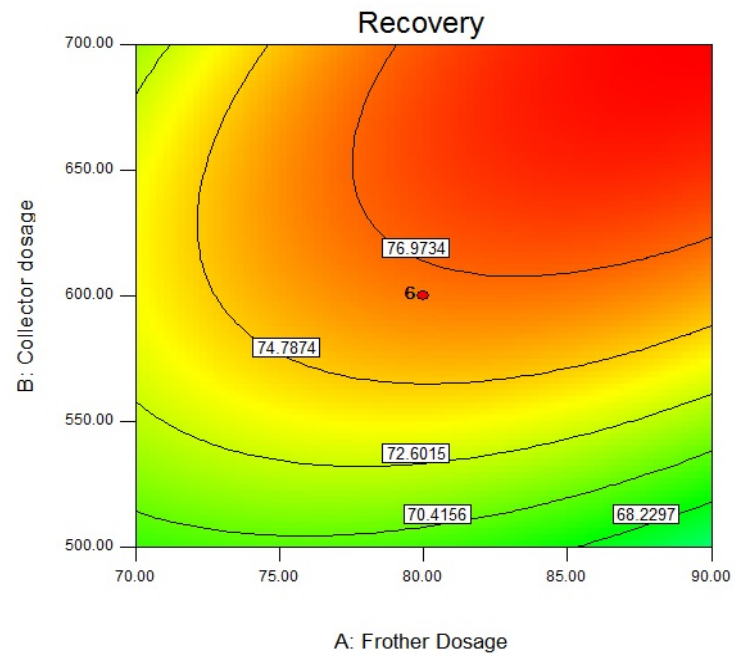

Figure 5. Effect of frother and collector dosages on Mo grade in pH of 9.77 (countor plot)
Figure 6 and 7 show the effect of frother and collector dosages on Mo grade. They are stated that both frother and collector concentration effect on the Mo grade in the constant $\mathrm{pH}=9.77$.

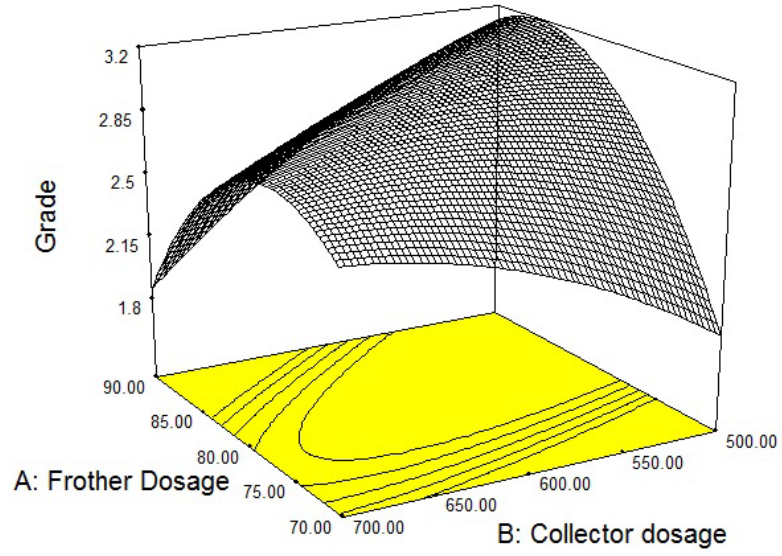

Figure 6. Effect of frother and collector dosages on Mo grade (\%) in $\mathrm{pH} 9.77$

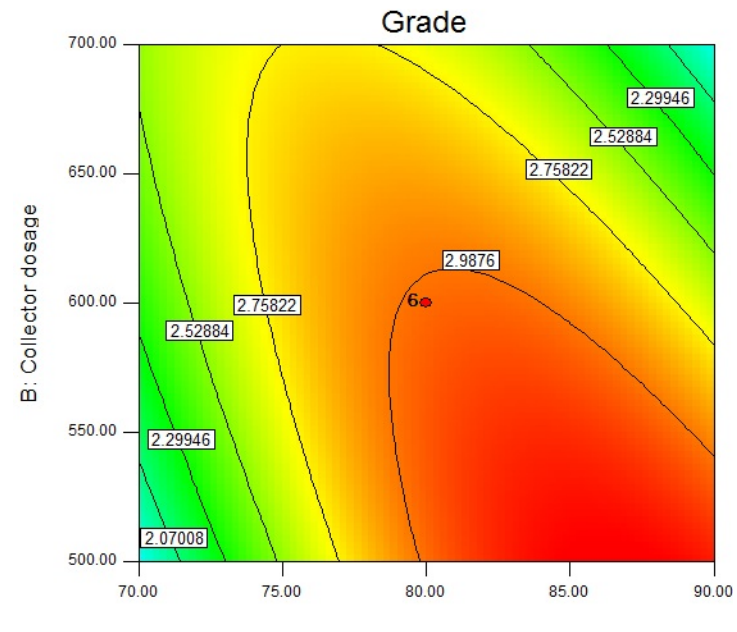

A: Frother Dosage

Figure 7. Effect of frother and collector dosages on Mo grade (countor plot)

As seen in Figure 8, Mo grade with increasing in collector and $\mathrm{pH}$, increased until $2.93 \%$ and then decreased.

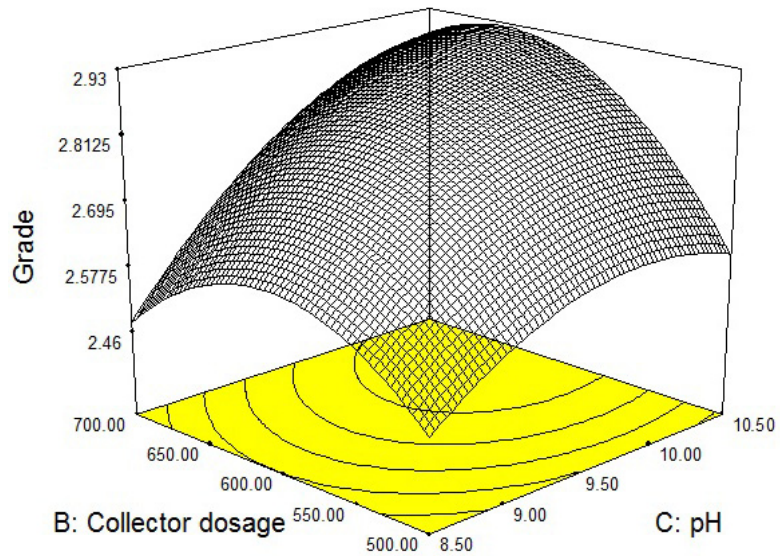

Figure 8. Effect of collector dosage and pH on Mo grade (\%) in frother dosage of $78.93 \mathrm{~g} / \mathrm{t}$ 


\subsection{Propagation of error}

Propagation of error (POE) is a tool to find controllable factors settings that maximize quality, which we define as making a product to target with minimum variation. It requires construction of mathematical models via response surface methods (RSM) (Brown, Box, \& Draper, 1990). Using the RSM and the POE techniques, we seek levels of the controllable factors that center response values on their respective targets while simultaneously reducing variation transmitted to the response from variation (lack-of-control) in the controllable factors (Whitcomb \& Anderson, 1996). In designed experiments, variations of frother dosage, collector dosage and $\mathrm{pH}$ were calculated $1,2 \mathrm{~g} / \mathrm{t}$ and 0.05 , respectively. Figures 9 and 10 illustrate the effect of frother and collector dosages on the POE values of the Mo recovery and grade, respectively.

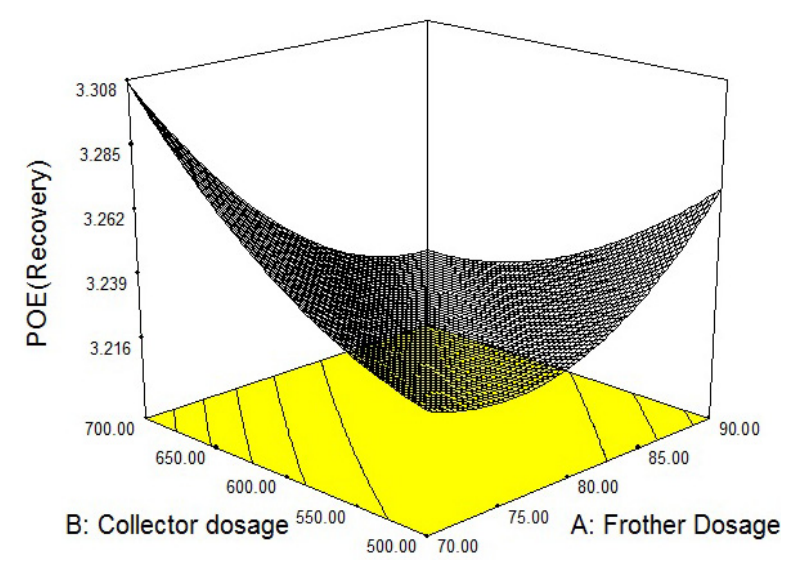

Figure 9. Effect of frother and collector dosages on POE values of Mo recovery

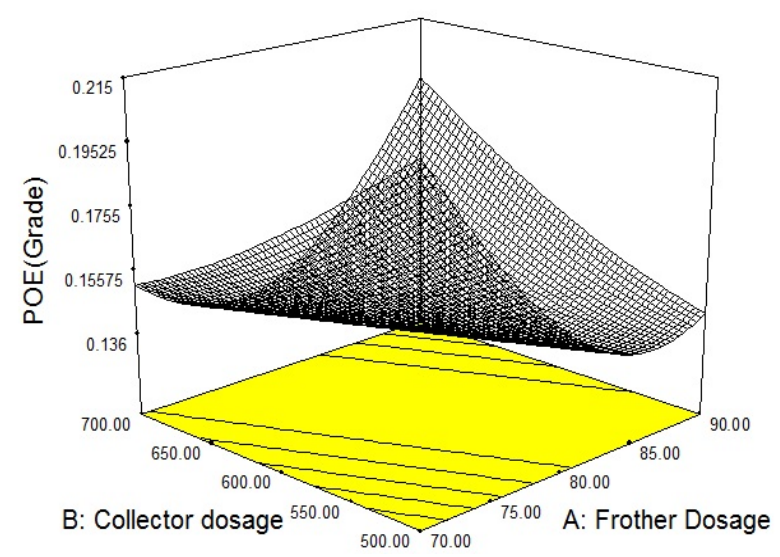

Figure 10. Effect of frother and collector dosages on POE values of Mo grade

In Figure 9 frother concentration increased POE in upper collector dosage, while its effect was conversed in lower collector dosages but in Figure10 in lower dosage of collector, frother decreased POE and then increased POE.

\subsection{Optimization}

Finding a desirable point in the design space is the goal of response surface optimization. The optimum point could be an extremum, or an area where the response is stable over a range of factors. A simultaneous optimization method was used by DX7 software to optimize the responses. In this work, the POE minimized to obtain robust recovery and grade against factor variations, so POE values were minimized in all optimization cases.

In Table 5 optimum conditions and limit of them is shown. Table 6 shows the results for optimum conditions.

Table 5. Optimum process conditions

\begin{tabular}{lccc}
\hline \multicolumn{1}{c}{ Name } & Goal & Limit & Limit \\
\hline Frother Dosage & minimize & 70 & 90 \\
Collector dosage & minimize & 500 & 700 \\
pH & is in range & 8.5 & 10.5 \\
POE (Recovery) & minimize & 3.22 & 3.35 \\
Grade & maximize & 1.34 & 3.2 \\
POE (Grade) & minimize & 0.14 & 0.23 \\
\hline
\end{tabular}

Table 6. Optimum process results

\begin{tabular}{cccccccc}
\hline \multicolumn{8}{c}{ Solution } \\
\hline $\begin{array}{c}\text { Frother Collector } \\
\text { Dosage } \\
\text { dosage }\end{array}$ & pH & $\begin{array}{c}\text { Re- } \\
\text { covery (Recovery) }\end{array}$ & Prade & $\begin{array}{c}\text { POE } \\
\text { (Grade) }\end{array}$ & $\begin{array}{c}\text { Desira- } \\
\text { bility }\end{array}$ \\
\hline 78.93 & 507.7 & 9.77 & 79.13 & 3.22 & 2.93 & 0.15 & 0.82 \\
\hline
\end{tabular}

Maximum Mo recovery was reached to $79.13 \%$ using $78.93 \mathrm{~g} / \mathrm{t} \mathrm{MIBC}, 507.7 \mathrm{~g} / \mathrm{t}$ gasoline and $\mathrm{pH}$ 9.77. Maximum grade also is $2.93 \%$ with minimum consumption of the flotation reagents were followed.

\section{CONCLUSIONS}

Modelling and optimization of the Mo flotation process from a low-grade Uranium ore containing $0.2 \% \mathrm{Mo}$ was performed, using response surface methodologycentral composite design (RSM-CCD). Frother (MIBC) dosage, collector (Gasoline) dosage and pulp pH were the control factors in this study. Four quadratic models for Mo recovery and Mo grade in the molybdenite concentrate were developed. Process optimization was carried out in Table 6. In recovery and grade, POE value was minimized. Some of the most important conclusions derived from optimization studies are as follows:

- maximum Mo recovery of $79.13 \%$ was obtained using $78.93 \mathrm{~g} / \mathrm{t}$ MIBC, $507.7 \mathrm{~g} / \mathrm{t}$ gasoline in pulp $\mathrm{pH}$ of 9.77;

$-2.93 \%$ for Mo grade of was obtained using $78.93 \mathrm{~g} / \mathrm{t}$ MIBC $507.7 \mathrm{~g} / \mathrm{t}$ gasoline in $\mathrm{pH}$ of 9.77 .

\section{ACKNOWLEDGEMENTS}

The financial support of the Jaber Ibn Hayan Research Laboratories, Nuclear Science and Technology Research Institute and Mr. Hasan Sedighi helps and the university of Imam Khomeini (IKIU) is gratefully acknowledged.

\section{REFERENCES}

Anderson, M.J., \& Whitcomb, P.J. (2007). DOE Simplified Practical Tools for Effective Experimentation. London: CRC Press, Taylor \& Francis Group.

Bezerra, M.A., Santelli, R.E., Oliveira, E.P., Villar, L.S., \& Escaleira, L.A. (2008). Response Surface Methodology (RSM) as a Tool for Optimization in Analytical Chemistry. Talanta, 76(5), 965-977.

https://doi.org/10.1016/j.talanta.2008.05.019 
Biswas, A.K., \& Davenport, W.G. (2013). Extractive Metallurgy of Copper: International Series on Materials Science and Technology. Netherlands: Elsevier.

Brown, R.A., Box, G.E.P., \& Draper, N.R. (1990). Empirical Model-Building and Response Surfaces. Biometrics, 46(1), 283-284.

https://doi.org/10.2307/2531659

Bulatovic, S.M., Wyslouzil, D.M., \& Kant, C. (1998). Operating Practices in the Beneficiation of Major Porphyry Copper/Molybdenum Plants from Chile: Innovated Technology and Opportunities, A Review. Minerals Engineering, 11(4), 313-331.

https://doi.org/10.1016/s0892-6875(98)00011-9

Fuerstenau, M.C., Jameson, G.J., \& Yoon, R.H. (2007). Froth Flotation: A Century of Innovation. Dearborn: SME.

Garner, C.D. (1994). The Chemical Nature of the Molybdenum Centres in Enzymes. Studies in Inorganic Chemistry, 403-418. https://doi.org/10.1016/b978-0-444-88198-4.50012-7

Grice, J.V., \& Montgomery, D.C. (2000). Design and Analysis of Experiments. Technometrics, 42(2), 208-209. https://doi.org/10.2307/1271458

Gupta, C.K. (1992). Extractive Metallurgy of Molybdenum. London: CRC Press, Taylor \& Francis Group.

Hernlund, R.W. (1961). Extraction of Molybdenite from Copper Fotation Products. Colorado School of Mines Quarterly, 56(3), 179-196.

Mason, R.L., Gunst, R.F., \& Hess, J.L. (2003). Statistical Design and Analysis of Experiments. Hoboken: John Wiley \& Sons. https://doi.org/10.1002/0471458503

Rath, R., \& Subramanian, S. (1999). Adsorption, Electrokinetic and Differential Flotation Studies on Sphalerite and Galena Using Dextrin. International Journal of Mineral Processing, 57(4), 265-283.

https://doi.org/10.1016/s0301-7516(99)00028-9
Rubio, J., Capponi, F., Rodrigues, R.T., \& Matiolo, E. (2007). Enhanced Flotation of Sulfide Fines Using the Emulsified Oil Extender Technique. International Journal of Mineral Processing, 84(1-4), 41-50. https://doi.org/10.1016/j.minpro.2007.04.002

Schena, G., \& Casali, A. (1994). Column Flotation Circuits in Chilean Copper Concentrators. Minerals Engineering, 7(12), 1473-1486. https://doi.org/10.1016/0892-6875(94)90039-6

Shirley, A., \& Sutulov, J.F. (1985). Molybdenum. New York: AIME.

Smit, F.J., \& Bhasin, A.K. (1985). Relationship of Petroleum Hydrocarbon Characteristics and Molybdenite Flotation. International Journal of Mineral Processing, 15(1-2), 19-40. https://doi.org/10.1016/0301-7516(85)90021-3

Triffett, B., Veloo, C., Adair, B.J.I., \& Bradshaw, D. (2008). An Investigation of the Factors Affecting the Recovery of Molybdenite in the Kennecott Utah Copper Bulk Flotation Circuit. Minerals Engineering, 21(12-14), 832-840. https://doi.org/10.1016/j.mineng.2008.03.003

Whitcomb, P.J., \& Anderson, M.J. (1996). Robust DesignReducing Transmitted Variation: Finding the Plateaus via Rresponse Surface Methods. In Annual Quality Congress Proceedings-American Society for Quality Control, (pp. 642-651). Chicago: American Society for Quality.

Yin, W., Zhang, L., \& Xie, F. (2010). Flotation of Xinhua Molybdenite Using Sodium Sulfide as Modifier. Transactions of Nonferrous. Metals Society of China, 20(4), 702-706. https://doi.org/10.1016/s1003-6326(09)60201-6

Zanin, M., Ametov, I., Grano, S., Zhou, L., \& Skinner, W. (2009). A Study of Mechanisms Affecting Molybdenite Recovery in a Bulk Copper/Molybdenum Flotation Circuit. International Journal of Mineral Processing, 93(3-4), 256-266. https://doi.org/10.1016/j.minpro.2009.10.001

\section{ОПТИМІЗАЦІЯ ПРОЦЕСУ ФЛОТАЦІЇ МОЛІБДЕНІТУ ЗА ДОПОМОГОЮ МЕТОДУ ПОВЕРХНІ ВІДГУКУ}

\section{Р. Бадрі, А.Р. Ханчі, А.Р. Зояжі, А.А. Рахмані}

Мета. Дослідження особливостей процесу флотації молібденіту з низькозбагаченої уранової руди, що містить $0.2 \%$ молібдену.

Методика. Проаналізовано три контрольних параметра флотації - дозу спінювача (метил-ізобутилкарбінол), колекторне (газолінове) дозування і ph (кожен - у п’яти різницях рівнів). Для статистичного розрахунку, аналізу експериментів і моделювання процесу флотації застосовано метод поверхневого відклику (МПВ). Були розроблені чотири квадратичні математичні моделі для розрахункових даних отримання Мо і визначення його якості.

Результати. Встановлено, що спінювач і колекторне дозування є найбільш впливовими факторами при отриманні Мо та його якості. У процесі оптимізації максимальні рівні отримання Мо та якості були, відповідно, $79.13 \%$ і 2.93\%. Виявлено наступну оптимальну концентрацію для Мо: спінювач - 78.93 г/т, газолінове дозування -507.70 г/т, $\mathrm{pH}-9.7$, що підтверджено моделюванням.

Наукова новизна. Запропоновано інноваційний підхід для отримання легкого й оптимального способу відновлення і ступеня вилучення урану до високої якості.

Практична значимість. Метод поверхневого відклику може ефективно застосовуватися для моделювання процесу флотації з метою визначення оптимальних умов досягнення максимальної рекуперації та якості при мінімальних витратах флотаційних реагентів.

Ключові слова: молібденіт, флотація, метод поверхневого відклику, иентральний композиційний план, схема проведення експериментів

\section{ОПТИМИЗАЦИЯ ПРОЦЕССА ФЛОТАЦИИ МОЛИБДЕНИТА ПОСРЕДСТВОМ МЕТОДА ПОВЕРХНОСТНОГО ОТКЛИКА}

\section{Р. Бадри, А.Р. Ханчи, А.Р. Зояжи, А.А. Рахмани}

Цель. Исследование особенностей процесса флотации молибденита из низкообогащенной урановой руды, содержащей $0.2 \%$ молибдена. 
Методика. Проанализированы три контрольных параметра флотации - доза вспенивателя (метил-изобутилкарбинол), коллекторная (газолиновая) дозировка и рН (каждый - в пяти разностях уровней). Для статистического расчета, анализа экспериментов и моделирования процесса флотации применен метод поверхности отклика (МПО). Были разработаны четыре квадратичные математические модели для расчетных данных получения Мо и определения его качества.

Результаты. Установлено, что вспениватель и коллекторная дозировка являются наиболее влияющими факторами при получении Мо и его качества. В процессе оптимизации максимальные уровни получения Мо и качества были, соответственно, 79.13\% и 2.93\%. Выявлена следующая оптимальная концентрация для Мо: вспениватель - 78.93 г/т, газолиновая дозировка - 507.70 г/т, $\mathrm{pH}-9.7$, что подтвержденно моделированием.

Научная новизна. Предложен инновационный подход для получения легкого и оптимального способа восстановления и степени извлечения урана до высокого качества.

Практическая значимость. Метод поверхностного отклика может эффективно применяться для моделирования процесса флотации с целью определения оптимальных условий достижения максимальной рекуперации и качества при минимальном расходе флотационных реагентов.

Ключевые слова: молибденит, флотация, метод поверхностного отклика, цчентральный композищионный план, схема проведения экспериментов

\section{ARTICLE INFO}

Received: 21 October 2017

Accepted: 22 December 2017

Available online: 26 December 2017

\section{ABOUT AUTHORS}

Rezgar Badri, PhD Student of the School of Mining Engineering, University of Tehran, $16^{\text {th }}$ Azar St, Enghelab Sq, 14174/66191, Tehran, Iran. E-mail: rezgarbadri08@yahoo.com

Ali Reza Khanchi, Doctor of Philosophy, Associate Professor of the Jaber Ibn Hayan Research Laboratories, Nuclear Science and Technology Research Institute, North Karegar Ave., 14399/51113, Tehran, Iran. E-mail: dockhanchi@yahoo.com

Ali Reza Zojaji, PhD Student of the School of Mining Engineering, University of Tehran, 16 ${ }^{\text {th }}$ Azar St, Enghelab Sq, 14174/66191, Tehran, Iran. E-mail: alirezazojaji227@gmail.com

Ali Akbar Rahmani, Doctor of Philosophy, Associate Professor of the College of Engineering, University of Imam Khomeini, Persian Gulf Ave., 34148/96818, Qazvin, Iran. E-mail: rezgarbadri08@yahoo.com 